\title{
Treatment of wastewater effluents from paper-recycling plants by coagulation process and optimization of treatment conditions with response surface methodology
}

\author{
Noushin Birjandi • Habibollah Younesi • \\ Nader Bahramifar
}

Received: 11 September 2013/ Accepted: 1 September 2014/Published online: 16 September 2014

(c) The Author(s) 2014. This article is published with open access at Springerlink.com

\begin{abstract}
In the present study, a coagulation process was used to treat paper-recycling wastewater with alum coupled with poly aluminum chloride $(\mathrm{PACl})$ as coagulants. The effect of each four factors, viz. the dosages of alum and $\mathrm{PACl}, \mathrm{pH}$ and chemical oxygen demand (COD), on the treatment efficiency was investigated. The influence of these four parameters was described using response surface methodology under central composite design. The efficiency of reducing turbidity, COD and the sludge volume index (SVI) were considered the responses. The optimum conditions for high treatment efficiency of paper-recycling wastewater under experimental conditions were reached with numerical optimization of coagulant doses and $\mathrm{pH}$, with $1,550 \mathrm{mg} / \mathrm{l}$ alum and 1,314 $\mathrm{mg} / \mathrm{PACl}$ and 9.5, respectively, where the values for reduction of $80.02 \%$ in COD, $83.23 \%$ in turbidity, and $140 \mathrm{ml} / \mathrm{g}$ in SVI were obtained.
\end{abstract}

Keywords Coagulation - Paper-recycling wastewater · Alum $\cdot$ Polyaluminum chloride

\section{Introduction}

The pulp and paper mills are among the most important industries in the world, but also some of the biggest polluting agents, discharging a variety of pollutants such as gaseous, liquid and solid wastes into the environment. The pollution of water bodies is of major global concern, because these industries generate large volumes of

N. Birjandi $\cdot$ H. Younesi $(\bowtie) \cdot$ N. Bahramifar Department of Environmental Science, Faculty of Natural Resources, Tarbiat Modares University, P.O. Box 46414-356, Noor, Iran

e-mail: hunesi@modares.ac.ir; hunesi@yahoo.com wastewater, viz. about $80 \mathrm{~m}^{3}$ of wastewater for each ton of pulp produced (Oguz and Keskinler 2008). More than 250 chemicals produced at different stages of paper production have been identified in the effluents (Thompson et al. 2001). According to research reports, samples with biodegradability index $\left(\mathrm{BOD}_{5} / \mathrm{COD}\right)$ smaller than 0.3 are not appropriate for biological degradation (Helble et al. 1999), as for complete biodegradation the effluent must present an index of at least 0.40 (Chamarro et al. 2001).

Paper mill wastewater can cause considerable damage to the recipient waters due to the high chemical oxygen demand (COD) and high toxicity. To minimize the impact of effluents on the environment, several treatment technologies have been employed, although little is known on their efficiency to eliminate the toxicity attributed to the presence of organic compounds. This is mainly due to the fact that it is the type of paper mills (packaging, recycling, kraft) and the water system configuration that determine the COD, toxicity and organic load of the effluent. Therefore, the design and efficiency of wastewater treatments will vary from mill to mill (Latorre et al. 2007). Thompson et al. (2001) reviewed the different types of treatment of pulp and paper mill effluents and indicated effective processes to minimize the discharge of wastewater to the environment. Coagulation is one of the most used water effluent treatments. It employs a cationic metal as a coagulant agent which usually promotes water hydrolysis and the formation of hydrophobic hydroxide compounds with different charges, depending on the solution $\mathrm{pH}$. It may also lead to the formation of polymeric compounds. The coagulants interact with colloidal materials by either charge neutralization or adsorption, leading to coagulation usually followed by sedimentation (Stephenson and Duff 1996). The coagulation effectiveness and cost depend on the coagulant type and concentration, solution $\mathrm{pH}$, ionic strength as well as on 
both concentration and nature of the organic residues in the effluent (Afzal et al. 2008). The response surface methodology (RSM) is a statistical technique for designing experiments, building models, evaluating the effects of several factors, searching optimum conditions for desirable responses and reducing the number of experiments (Wang et al. 2007). RSM has been proposed to determine the influence of individual factors and their interactive influence. It uses an experimental design such as the central composite design (CCD) in order to fit a modeling by the least squares technique, and the adequacy of the proposed model is then revealed using the diagnostic checking tests (Anderson-Cook et al. 2009).

The main objective of this work was to optimize the coagulation process and investigate the interactive effects of the experimental factors, viz. the coagulant dosages, $\mathrm{pH}$ and initial value of COD as process parameters. For this purpose, paper-recycling wastewater was selected as the target to be treated by the coagulation process, optimizing it by RSM under Design-Expert software. The quadratic models obtained were used in a constrained optimization to achieve optimum process conditions for maximum removal efficiencies of turbidity and COD and the lowest sludge volume index (SVI) of the paper-recycling wastewater.

\section{Materials and methods}

\section{Analytical methods}

The paper-recycling wastewater used in this work was taken from Afrang Paper Manufacture Ltd., Iran. The wastewater samples were characterized according to standard methods for the examination of water and wastewater (APHA 1998) and the results are given in Table 1. Alum and $\mathrm{PACl}$ (Merck) were used as coagulants. The initial solution $\mathrm{pH}$ of the paper-recycling wastewater was adjusted using $1.0 \mathrm{~mol} / \mathrm{l}$ sodium hydroxide and $0.5 \mathrm{~mol} / 1$ sulfuric acid solution. A calorimetric method with closed reflux was developed for the measurement of COD (the Plaintest system, photometer 8000, England) at $600 \mathrm{~nm}$, which was used to measure the absorbance of the COD samples. A pH meter (the Waterproof CyberScan PC 300, Singapore) was used to measure the solution $\mathrm{pH}$. Turbidity was measured by a turbidity meter (the CyberScan TB 1000 Eutech Instruments, Singapore). The SVI was measured using a 1,000 ml Imhoff cone (APHA 1998).

\section{Experimental procedure}

The coagulation experiments were performed with $100 \mathrm{ml}$ paper-recycling wastewater, adjusting the initial COD and $\mathrm{pH}$ at different values. In a typical run, the paper-recycling
Table 1 Chemical and physical characteristics of the wastewater used

\begin{tabular}{lll}
\hline Characteristics & Range & Mean \\
\hline Color & Brown & - \\
$\mathrm{pH}$ & $6.32-7.60$ & 6.5 \\
$\mathrm{COD}(\mathrm{mg} / \mathrm{l})$ & $3,348-3,765$ & 3,523 \\
$\mathrm{BOD}_{5}(\mathrm{mg} / \mathrm{l})$ & $870-974$ & 940 \\
$\mathrm{TS}(\mathrm{mg} / \mathrm{l})$ & $3,067-3,307$ & 3,260 \\
TSS $(\mathrm{mg} / \mathrm{l})$ & $245-267$ & 260 \\
Ash $(\mathrm{mg} / \mathrm{l})$ & $1,206-1,345$ & 1,320 \\
Turbidity $(\mathrm{TNU})$ & $855-880$ & 873 \\
Phosphate $(\mathrm{mg} / \mathrm{l})$ & $68-76$ & 73 \\
Sulfate $(\mathrm{mg} / \mathrm{l})$ & $45-55$ & 50 \\
Nitrate $(\mathrm{mg} / \mathrm{l})$ & $0.89-1.12$ & 1.03 \\
Nitrite $(\mathrm{mg} / \mathrm{l})$ & $0.07-0.13$ & 0.10 \\
Chloride $(\mathrm{mg} / \mathrm{l})$ & $9.8-11.1$ & 10.7 \\
\hline
\end{tabular}

wastewater was diluted with tap water to adjust its COD concentration to the desired value. Then different concentrations of coagulants were progressively added. The samples were stirred at $50 \mathrm{rpm}$ (Velp scientific magnetic stirrer) for $2 \mathrm{~min}$ to completely dissolve the coagulant. This was followed by a further slow mixing for $20 \mathrm{~min}$ at $40 \mathrm{rpm}$. The flocks formed were allowed to settle for $30 \mathrm{~min}$. After settling, the turbidity and final COD of the supernatant were determined. The remaining portion of the treated wastewater samples was used to determine the SVI.

Experimental design for optimization of parameters

The RSM was applied for developing, improving and optimizing the processes and to evaluate the relative significance of several affecting factors even in the presence of complex interactions. In the present study, the DesignExpert 7.0 (State-Ease, Inc., Minneapolis, MN, USA) software was used for regression and graphical analyses of the obtained data. RSM, as a robust design technology based on the central composite design (CCD), could be applied to the modeling and analysis of multiple parameters. The experimental design had with four different factors: solution $\mathrm{pH}$, initial COD value, alum dosage, $\mathrm{PACl}$ dosage. Each of the parameters was coded at five levels: $-\alpha,-1,0,+1$ and $+\alpha$. A CCD involves a two-level factorial $\left(k^{2}\right)$ design, $2 k$ axial points (denoted by $\pm \alpha$ ), and $n_{\mathrm{c}}$ center points. In this study, the goal was to create a full factorial design at the $k=4$ design, completely randomized, in one block with six center points and the axial distance $\alpha=2$ for a rotatable design. The range and level of the variables in coded units from the RSM studies are given in Table 2. For statistical calculations, the variable $X_{i}$ was coded as $x_{i}$, according to the following equation: 
$x_{i}=\frac{X_{i}-X_{0}}{\Delta X}$

where $X_{i}$ is the uncoded value of the independent variable, $i, X_{0}$ is the value of $X_{i}$ at the center point of the investigated area and $\Delta X$ is the step change. Table 3 shows the coded

Table 2 Experimental ranges and levels of the independent variables

\begin{tabular}{llllll}
\hline Independent variables & \multicolumn{5}{l}{ Range and level } \\
\cline { 2 - 6 } & $-\alpha$ & -1 & 0 & +1 & $+\alpha$ \\
\hline COD (A) & 250 & 750 & 1,250 & 1,750 & 2,250 \\
Alum dosage [mg/l (B)] & 200 & 650 & 1,100 & 1,550 & 2,000 \\
PACl dosage [mg/l (C)] & 55 & 420 & 785 & 1,150 & 1,515 \\
pH (D) & 2 & 4.5 & 7 & 9.5 & 12 \\
\hline
\end{tabular}

and uncoded variables for the four experimental variables according to the Eq. (1). To obtain the optimum dosages, initial $\mathrm{COD}$ and $\mathrm{pH}$, three dependent parameters were analyzed as response, final COD and turbidity removal efficiencies and SVI value. The quadratic equation model for predicting the optimal conditions can be expressed according to $\mathrm{Eq}(2)$ as follows:

$$
Y=\beta_{0}+\sum_{i=1}^{k} \beta_{i} x_{i}+\sum_{i=1}^{k} \beta_{i i} x_{i}^{2}+\sum_{i=1}^{k-1} \sum_{j=2}^{k} \beta_{i j} x_{i} x_{j}+\varepsilon
$$

where $(i)$ is the linear coefficient, (ii) the quadratic coefficient $(\beta)$ the regression coefficient, $(i j)$ the interaction coefficient, $(k)$ the number of factors studied and optimized in the experiment and $(\varepsilon)$ the random error. The experiments were carried out according to the experimental data

Table 3 Experimental design based on central composite design (CCD) used in this study

\begin{tabular}{|c|c|c|c|c|c|c|c|}
\hline \multirow[t]{2}{*}{ Run } & \multicolumn{4}{|c|}{ Uncoded (coded) values } & \multicolumn{3}{|l|}{ Responses } \\
\hline & $A$ & $B$ & $C$ & $D$ & Final COD removal (\%) & Turbidity (\%) & $\mathrm{SVI}(\mathrm{ml} / \mathrm{g})$ \\
\hline 1 & $750(-1)$ & $1,550(+1)$ & $1,150(+1)$ & $4.5(-1)$ & 84 & 69 & 244 \\
\hline 2 & $2,250(+\alpha)$ & $1,100(0)$ & $785(0)$ & $7(0)$ & 73 & 91 & 295 \\
\hline 3 & $1,750(+1)$ & $650(-1)$ & $420(-1)$ & $4.5(-1)$ & 79 & 77 & 400 \\
\hline 4 & $250(-\alpha)$ & $1,100(0)$ & $785(0)$ & $7(0)$ & 67 & 65 & 850 \\
\hline 5 & $750(-1)$ & $650(-1)$ & $1,150(+1)$ & $9.5(+1)$ & 80 & 46 & 994 \\
\hline 6 & $1,250(0)$ & $1,100(0)$ & $785(0)$ & $7(0)$ & 82 & 81 & 394 \\
\hline 7 & $1,250(0)$ & $1,100(0)$ & $55(-\alpha)$ & $7(0)$ & 84 & 83 & 805 \\
\hline 8 & $1,750(+1)$ & $650(-1)$ & $420(-1)$ & $9.5(+1)$ & 79 & 84 & 803 \\
\hline 9 & $1,250(0)$ & $1,100(0)$ & $1,515(+\alpha)$ & $7(0)$ & 88 & 80 & 205 \\
\hline 10 & $1,750(+1)$ & $650(-1)$ & $1,150(+1)$ & $9.5(+1)$ & 84 & 78 & 662 \\
\hline 11 & $1,750(+1)$ & $1,550(+1$ & $1,150(+1)$ & $4.5(-1)$ & 82 & 82 & 712 \\
\hline 12 & $1,750(+1)$ & $650(-1)$ & $1,150(+1)$ & $4.5(-1)$ & 80 & 77 & 354 \\
\hline 13 & $750(-1)$ & $650(-1)$ & $420(-1)$ & $4.5(-1)$ & 82 & 69 & 988 \\
\hline 14 & $750(-1)$ & $1,550(+1)$ & $420(-1)$ & $9.5(+1)$ & 72 & 72 & 889 \\
\hline 15 & $1,750(+1)$ & $1,550(+1)$ & $1,150(+1)$ & $9.5(+1)$ & 86 & 87 & 186 \\
\hline 16 & $1,250(0)$ & $1,100(0)$ & $785(0)$ & $7(0)$ & 83 & 77 & 371 \\
\hline 17 & $1,250(0)$ & $1,100(0)$ & $785(0)$ & $2(-\alpha)$ & 88 & 60 & 50 \\
\hline 18 & $1,250(0)$ & $200(-\alpha)$ & $785(0)$ & $7(0)$ & 80 & 58 & 1,690 \\
\hline 19 & $750(-1)$ & $650(-1)$ & $1,150(+1)$ & $4.5(-1)$ & 84 & 60 & 214 \\
\hline 20 & $750(-1)$ & $650(-1)$ & $420(-1)$ & $9.5(+1)$ & 75 & 68 & 1,970 \\
\hline 21 & $1,250(0)$ & $2,000(+\alpha)$ & $785(0)$ & $7(0)$ & 82 & 72 & 892 \\
\hline 22 & $1,250(0)$ & $1,100(0)$ & $785(0)$ & $7(0)$ & 82 & 79 & 355 \\
\hline 23 & $1,750(+1)$ & $1,550(+1)$ & $420(-1)$ & $4.5(-1)$ & 82 & 67 & 525 \\
\hline 24 & $750(-1)$ & $1,550(+1)$ & $1,150+1$ & $9.5(+1)$ & 75 & 67 & 297 \\
\hline 25 & $750(-1)$ & $1,550(+1)$ & $420(-1)$ & $4.5(-1)$ & 85 & 68 & 830 \\
\hline 26 & $1,250(0)$ & $1,100(0)$ & $785(0)$ & $7(0)$ & 83 & 76 & 269 \\
\hline 27 & $1,250(0)$ & $1,100(0)$ & $785(0)$ & $7(0)$ & 81 & 81 & 295 \\
\hline 28 & $1,250(0)$ & $1,100(0)$ & $785(0)$ & $12(+\alpha)$ & 83 & 69 & 347 \\
\hline 29 & $1,250(0)$ & $1,100(0)$ & $785(0)$ & $7(0)$ & 81 & 79 & 384 \\
\hline 30 & $1,750(+1)$ & $1,550(+1)$ & $420(-1)$ & $9.5(+1)$ & 81 & 84 & 93 \\
\hline
\end{tabular}

Initial COD $A$, alum dose $B, \mathrm{PACl}$ dose $C$, solution $\mathrm{pH} D$ 
Table 4 The developed models and ANOVA results for the response parameters

\begin{tabular}{|c|c|c|c|c|c|c|c|c|c|}
\hline Models in terms of coded values of parameters & $F$ value & $P$ value & $\begin{array}{l}F- \\
\text { LOF }\end{array}$ & $\begin{array}{l}P- \\
\mathrm{LOF}\end{array}$ & $R^{2}$ & $\begin{array}{l}\text { Adj. } \\
R^{2}\end{array}$ & $\begin{array}{l}\text { Pred. } \\
R^{2}\end{array}$ & $\begin{array}{l}\mathrm{CV} \\
(\%)\end{array}$ & AP \\
\hline $\begin{array}{l}Y_{\mathrm{COD}}=+82.00+1.17 A+0.33 B+1.17 C- \\
1.50 D+0.88 A B+0.13 A C+2.50 A D-0.37 \mathrm{BC}- \\
0.75 B D+1.00 C D-3.00 A^{2}-0.25 B^{2}+1.00 C^{2}+0.88 D^{2}\end{array}$ & 44.50 & $<0.0,001$ & 1.31 & 0.4028 & 0.9765 & 0.9545 & 0.8926 & 1.22 & 29.97 \\
\hline $\begin{array}{l}Y_{\text {Tur }}=+78.83+7.04 A+2.71 B-1.21 C+1.46 D- \\
1.81 A B+2.94 A C+2.69 A D+3.19 B C+1.94 B D-2.31 C D- \\
0.22 A^{2}-3.47 B^{2}+0.66 C^{2}-3.59 D^{2}\end{array}$ & 54.61 & $<0.0001$ & 0.79 & 0.6499 & 0.9808 & 0.9628 & 0.9214 & 2.57 & 33.03 \\
\hline $\begin{array}{l}Y_{\mathrm{SVI}}=+344.67-158.38 A-175.21 B- \\
168.13 C+92.54 D+75.19 A B+188.81 A C- \\
132.56 A D+64.94 B C-207.44 B D- \\
24.81 C D+55.81 A^{2}+235.47 B^{2}+38.97 C^{2}-37.66 D^{2}\end{array}$ & 156.90 & 0.0001 & 0.98 & 0.5448 & $\begin{array}{l}0.9932 \\
0.9708\end{array}$ & 0.9869 & 0.9708 & 8.41 & 53.558 \\
\hline
\end{tabular}

From this table, $Y$ is pollutant removal (response) in percentage, $A, B, C$ and $D$ are the coded values of the tests variables initial COD, alum dose, $\mathrm{PACl}$ dose and solution $\mathrm{pH}$, respectively, $A P$ adequate precision, $L O F$ lack-of-fit, $A d j . R^{2}$ adjusted $R^{2}$, Pred. $R^{2}$ predicted $R^{2}$

sheet (both coded and uncoded design matrices) shown in Table 3, which also lists the response values, i.e., COD removal, turbidity removal and SVI value. The results are further analyzed using Design-Expert Software. The relationship between the four controllable factors (Alum and $\mathrm{PACl}$ dosages, $\mathrm{pH}$ and initial COD) and the three important operating parameters (COD removal, turbidity removal and SVI) for coagulation process was studied.

\section{Results and discussion}

RSM approach of optimization of COD and turbidity removal and SVI value

The statistical significance of the quadratic model was evaluated by the analysis of variance (ANOVA), as presented in Table 4. The empirical relationship between the COD removal $\left(Y_{\mathrm{COD}}\right)$, turbidity removal $\left(Y_{\text {Tur }}\right)$ and SVI value $\left(Y_{\mathrm{SVI}}\right)$ and the four test variables in coded units by the application of RSM is given by quadratic models, as given in Table 4. The adequacy of the model was tested through lack-of-fit, $P$ values and $F$ values (Vohra and Satyanarayana 2002). The $P$ values for lack-of-fit were $0.4028,0.6499$ and 0.54488 for the removal of COD and turbidity and SVI value, respectively, which indicates that it is not statistically significant as is desirable. The insignificant value of lack-of-fit $(>0.05)$ shows that the model is valid for the present study (Ziagova et al. 2007). The $F$ values of 44.50, 54.61 and 156.90 were for COD removal and turbidity removal efficiency and SVI value, respectively, and $P$ values were significant $(P<0.05)$ (Table 4$)$. This means that the model terms are statistically significant and can predict response satisfactorily. The fit of the model was checked by determining the coefficient $\left(R^{2}\right)$. In this study, the $R^{2}$ values obtained were $0.9765,0.9880$ and 0.9932 for the removal of COD and turbidity and SVI value, respectively. The closer the $R^{2}$ is to 1 , the stronger is the model and the better it predicts the response. The value of the adjusted determination of the coefficient (adjusted $R^{2}=0$. 9545, 0.9628 and 0.9869) for COD and turbidity removal efficiency and SVI is also high, showing the high significance of the model. The values of the predicted $R^{2}$ at $0.8926,0.9214$ and 0.9708 obtained for the COD and turbidity removal efficiency and SVI value, respectively, were also high, supporting the considerable significance of the model. At the same time, the relatively low values of the coefficient of variation $\left(\mathrm{CV}_{\mathrm{COD}}=1.22, \mathrm{CV}_{\text {Tur }}=2.57\right.$ and $\left.\mathrm{CV}_{\mathrm{SVI}}=8.41\right)$ indicate a good precision and reliability of the experiments (Nakano and Jutan 1994; Collins et al. 2009). Adequate precision (AP) is a measure of the range in the predicted response relative to its associated error. Its desirable value is 4 or more. Adequate precision compares the range of the predicted values at the design points with the average prediction error. A ratio greater than 4 indicates an adequate model discrimination (Aghamohammadi et al. 2007; Ghafari et al. 2009). Usually it is necessary to check the fitted model to ensure that it provides an adequate approximation with the real system. Unless the model shows an adequate fit, proceeding with an investigation and optimization of the fitted response surface is likely to give poor or misleading results. Diagnostic plots such as the predicted versus actual values help us to judge the satisfactoriness of the model.

Figure 1 shows the plots for predicted versus actual values of the parameters for removal of the COD (a) and reduction of the turbidity (b) and SVI value (c). These plots indicate an adequate agreement between the uncoded data and the ones obtained from the models. By applying the diagnostic plots such as the ones for predicted versus actual values, the model adequacy can be judged. The regression equation after the ANOVA gave the level of COD and turbidity removal as a function of four factors, i.e., the dosages of alum and $\mathrm{PACl}$, initial solution $\mathrm{pH}$ and initial 

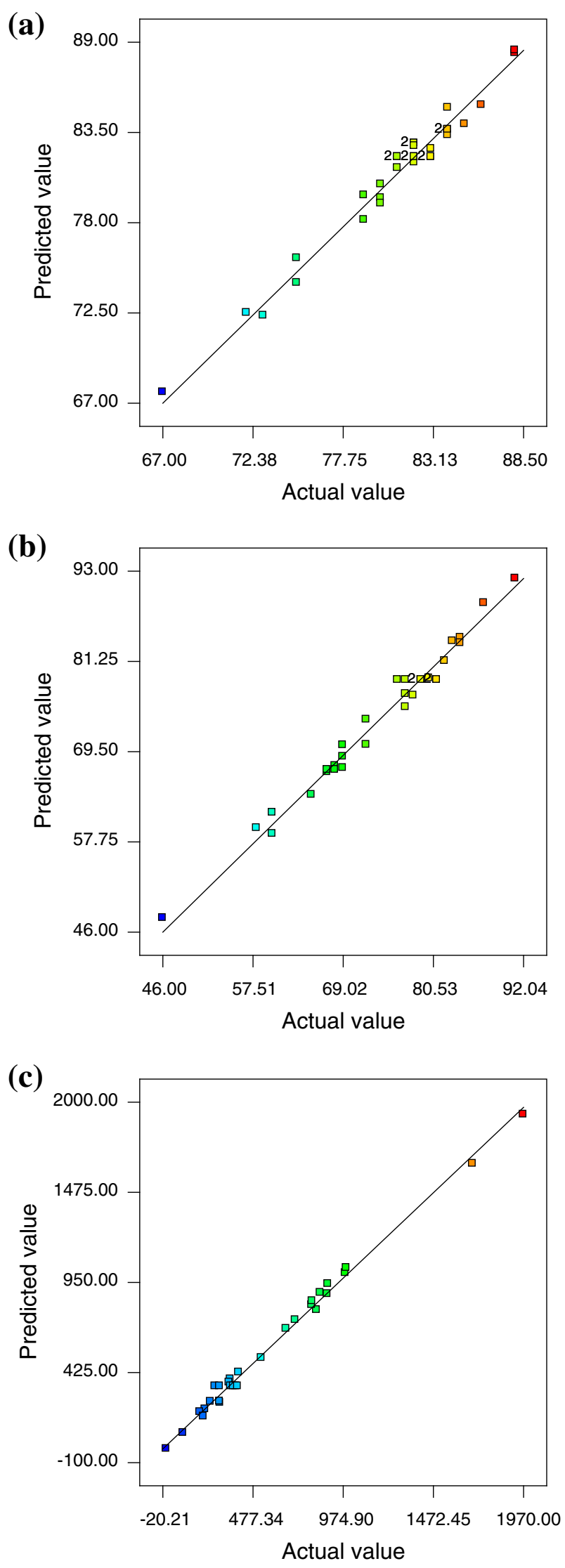

4 Fig. 1 Design-expert plot; predicted vs. actual values plot for a final COD removal $\left(R^{2}=0.9765\right)$, b turbidity removal $\left(R^{2}=0.9808\right)$ and c SVI $\left(R^{2}=0.9932\right)$. The colors changes from blue to red in the response value indicating 0 to $100 \%$ range

COD. After applying multiple regression analysis on the experimental data, the results of the CCD design were fitted with a second-order full polynomial equation.

Effect of different alum and PACl dosage on COD and turbidity reduction

In coagulation processes, three factors, viz. kind of an inorganic coagulant, the coagulant dosage and the $\mathrm{pH}$, play an important role in determining the coagulation process efficiency in wastewater. In treatments using inorganic coagulants, the optimum $\mathrm{pH}$ range in which metal hydroxide precipitates should be determined (Aguilar et al. 2002). Different coagulants affect different degrees of destabilization. The higher the valence of the counter ion, the more is its destabilizing effect and the less is the dose needed for coagulation (Birjandi et al. 2013). At high dose of metal ions (coagulant), a sufficient degree of oversaturation occurs to produce a rapid precipitation of a large quantity of metal hydroxide, enmeshing the colloidal particles which are termed as sweep floc (Hu et al. 2011).The effect of different levels of the alum and PACl doses on COD and turbidity removal efficiency can be predicted from the 3D plot, while the other two variables are at its middle level, as shown in Fig. 2. Figure 2a clearly shows that the COD removal efficiency increases with increasing coagulant dosages. The maximum COD removal (88.26\%) is shown with $657 \mathrm{mg} / \mathrm{l}$ dosage of alum and 1,500 mg/l dosage of PACl. Thus, for significant removal of COD, high doses of coagulants are needed. This is due to the presence of large amounts of organic matter in the wastewater and interaction with coagulants that can cause the suspended solids in the effluent to be oxidized, coagulated and then be settled as sludge; this process will reduce COD (Kumar et al. 2009). In Fig. 2b the effects of PACl dosage on turbidity reduction are not significant within the dosage range studied. The effect of increasing the $\mathrm{PACl}$ dosage only reveals a minor impact on the reduction-removal efficiency of turbidity. It can be seen that the maximum removal of turbidity $(84.8 \%)$ was obtained with approximately $853 \mathrm{mg} / \mathrm{l}$ dosage of alum and $53 \mathrm{mg} / \mathrm{l}$ dosage of $\mathrm{PACl}$. The addition of $\mathrm{PACl}$ in the effluent and its mixing create proper coagulation condition and the flocs generated are denser than water, hastening the settling of the flocs. The $\mathrm{PACl}$, having multivalent aluminum ions, neutralize the particle charges and the hydrolyzed aluminum flocs enmesh the colloids and drive to settle at high COD $(\mathrm{Hu}$ et al. 2011).

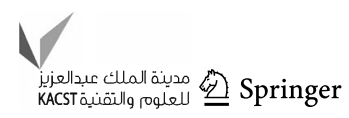



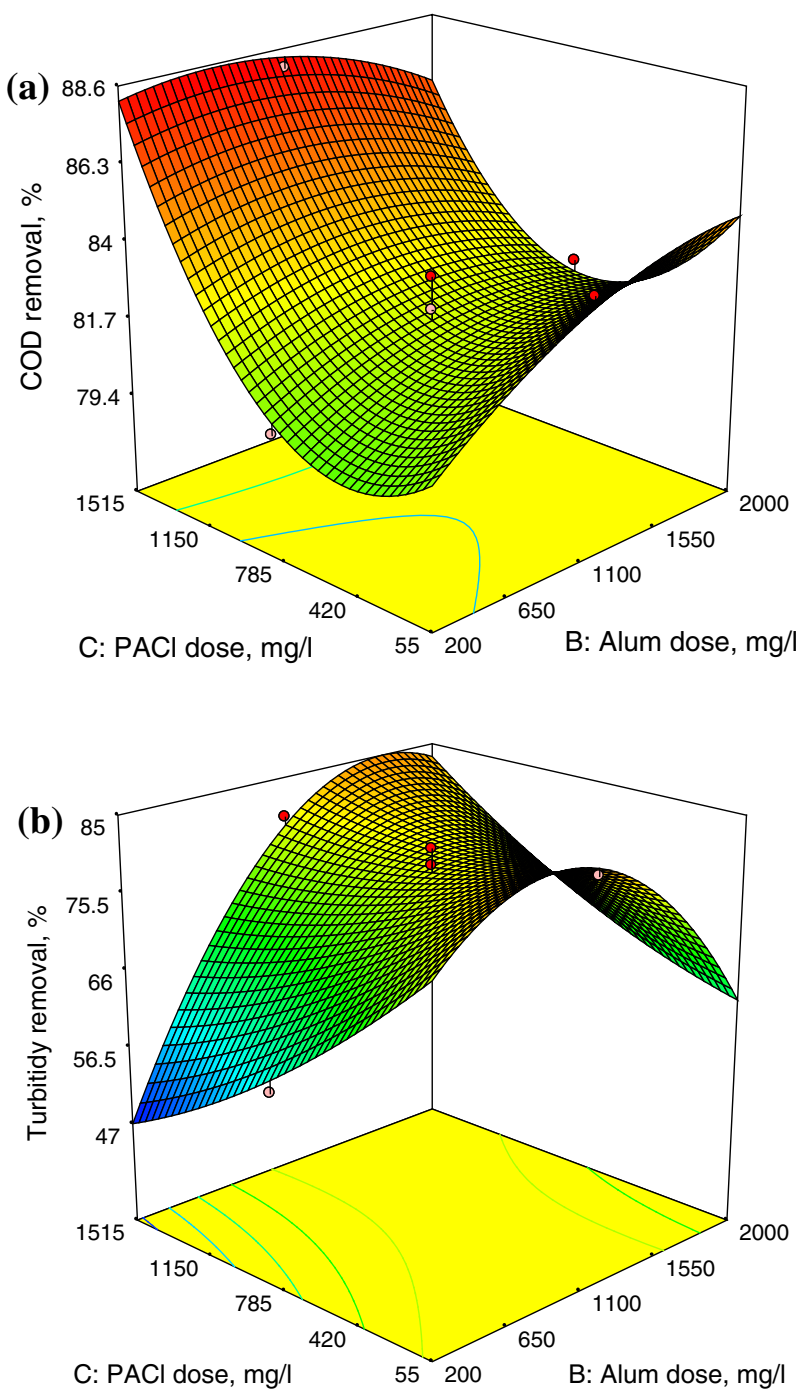

Fig. 2 Effect of coagulants doses on a COD removal, b turbidity reduction, while other two variables at its middle level. The colors changes from blue to red in the response value indicating 0 to $100 \%$ range

The use of alum alone is not a perfect method for treatment paper mill wastewater and it is best to investigate with the other methods treatment and coagulants that can be provide necessary standards for this effluent. Therefore, in paper-recycling wastewater treatment use of alum coupled with PACl could be the best results (Stephenson and Duff 1996).

Effect of solution $\mathrm{pH}$ and alum dose on COD and turbidity reduction

Changes in coagulants species and charge of the target compound can result due to variation in $\mathrm{pH}$ of the liquid media. In addition to governing the coagulant speciation, the media $\mathrm{pH}$ influences the extent of dissociation of the trace organic contaminants, and can result in compound- specific removal performance during application of a certain type of coagulant (Birjandi et al. 2013). The addition of metal coagulants depresses the wastewater $\mathrm{pH}$ to a lower value. The decrease in $\mathrm{pH}$ after the addition of coagulant may be due to the several hydrolytic reactions, which are taking place during coagulation, forming multivalent charged hydrous oxide species and generating $\mathrm{H}_{3} \mathrm{O}^{+}$ion during each step, thus reducing the $\mathrm{pH}$ value (Kumar et al. 2011).

It has also been reported that the coagulant addition depresses $\mathrm{pH}$ to highly acidic levels, as the coagulant dose is highly correlated with $\mathrm{pH}$ (Chaudhari et al. 2007). It is supposed that improvement of flocculation $\mathrm{pH}$ may reduce the alum dose needs for the optimization of the process. Figure 3 presents the effect of different levels of the $\mathrm{pH}$
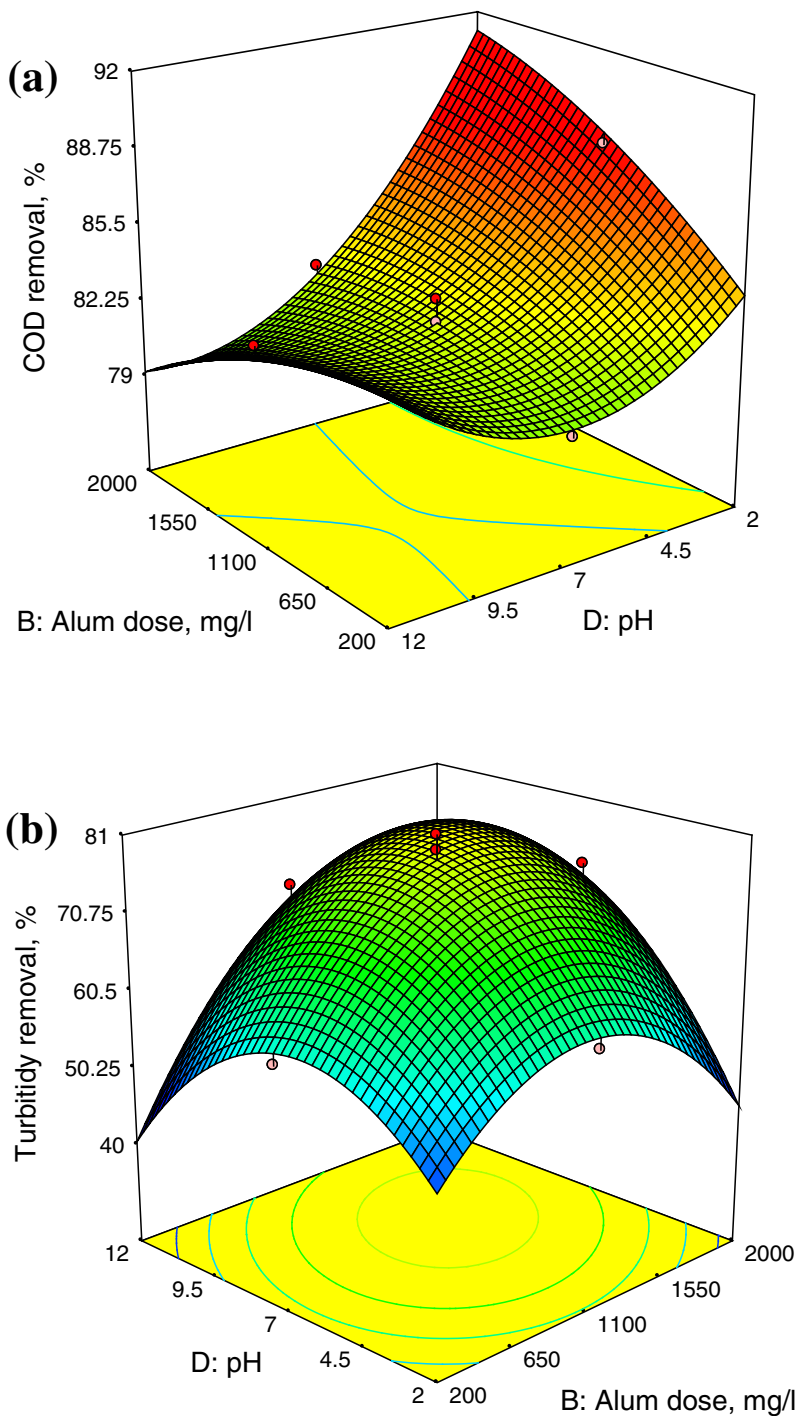

Fig. 3 Effect of $\mathrm{pH}$ and alum dose on a COD removal and $\mathbf{b}$ turbidity reduction, while other two variables at its middle level. The colors changes from blue to red in the response value indicating 0 to $100 \%$ range 
and the alum dose on the removal of COD and turbidity when other two variables at its middle level. Both the turbidity reduction and the COD removal efficiency increase with an decreasing $\mathrm{pH}$ adjustment till reach their highest value at the optimal $\mathrm{pH}$, between which the reduction efficiency values start to decrease. This confirms the findings of (Ahmad et al. 2008). Figure 3a shows that the maximum COD removal $(89.67 \%)$ can be obtained at $\mathrm{pH}=2.0$, but Fig. $3 \mathrm{~b}$ shows that the maximum turbidity reduction efficiency $(79.73 \%)$ occurs at $\mathrm{pH}=7.82$. It is well known that the $\mathrm{pH}$ of the solution affects the hydroxyl radical generating capacity (Zayas et al. 2007). According to Petala et al. (2006), at a lower $\mathrm{pH}$ and with a lower coagulant dosage, the only mechanism for destabilization of particles is through charge neutralization. At a low $\mathrm{pH}$, because the aggregates are small in size, the mechanism of colloidal destabilization is mainly charge neutralization. It can be said that the highest range of $\mathrm{pH}$ exists between 6.0 and 8.0, beyond which the effluent quality deteriorates. The most important reasons for such behaviours are: 1) at low $\mathrm{pH}$, the presence of monomeric aluminum species $\left[\mathrm{Al}^{3+}\right.$, $\mathrm{Al}(\mathrm{OH})^{2+}$ and $\mathrm{Al}(\mathrm{OH})_{2}{ }^{+}$] causes the anionic particles to neutral and deposition of pollutants settlement process is best performed due to the formation positive metal complexes that help to build flocs with the negative organic pollutants in wastewater, 2) with increase in $\mathrm{pH}$, the concentration of dissolved aluminum is reduced by the formation of uncharged metal hydroxide $\left[\mathrm{Al}(\mathrm{OH})_{3}\right]$ that leads to rapid precipation and 3) with further increase in $\mathrm{pH}$, the species $\mathrm{Al}(\mathrm{OH})_{4}{ }^{-}$is dominant which reduces coagulation effects and no coagulation occurs anymore (Ahmad et al. 2008).

Effect of initial COD and $\mathrm{pH}$ on final COD and turbidity removal efficiency

The experimental runs were conducted with five different initial COD values. The effect of different levels of the initial COD concentration and the $\mathrm{pH}$ on final COD and turbidity removal efficiency can be predicted from the 3D plot, while the other two variables are at its middle level, as shown in Fig. 4. Figure 4a shows that the maximum value of $89.67 \%$ for COD removal is found with an initial COD of $940 \mathrm{mg} / \mathrm{l}$ and that the COD removal efficiency decreases with a high initial COD value and with COD of $250 \mathrm{mg} / \mathrm{l}$ a COD removal efficiency of $58 \%$ is achieved. In contrast, the results obtained on turbidity show that high initial COD values result in high reduction efficiency (Fig. 4b). With COD of $250 \mathrm{mg} / \mathrm{l}$ (as the COD low limit value introduced to software), turbidity reduction efficiency of $42 \%$ is achieved, while the maximum value of $95 \%$ reduction is found at initial COD of $2,250 \mathrm{mg} / \mathrm{l}$.
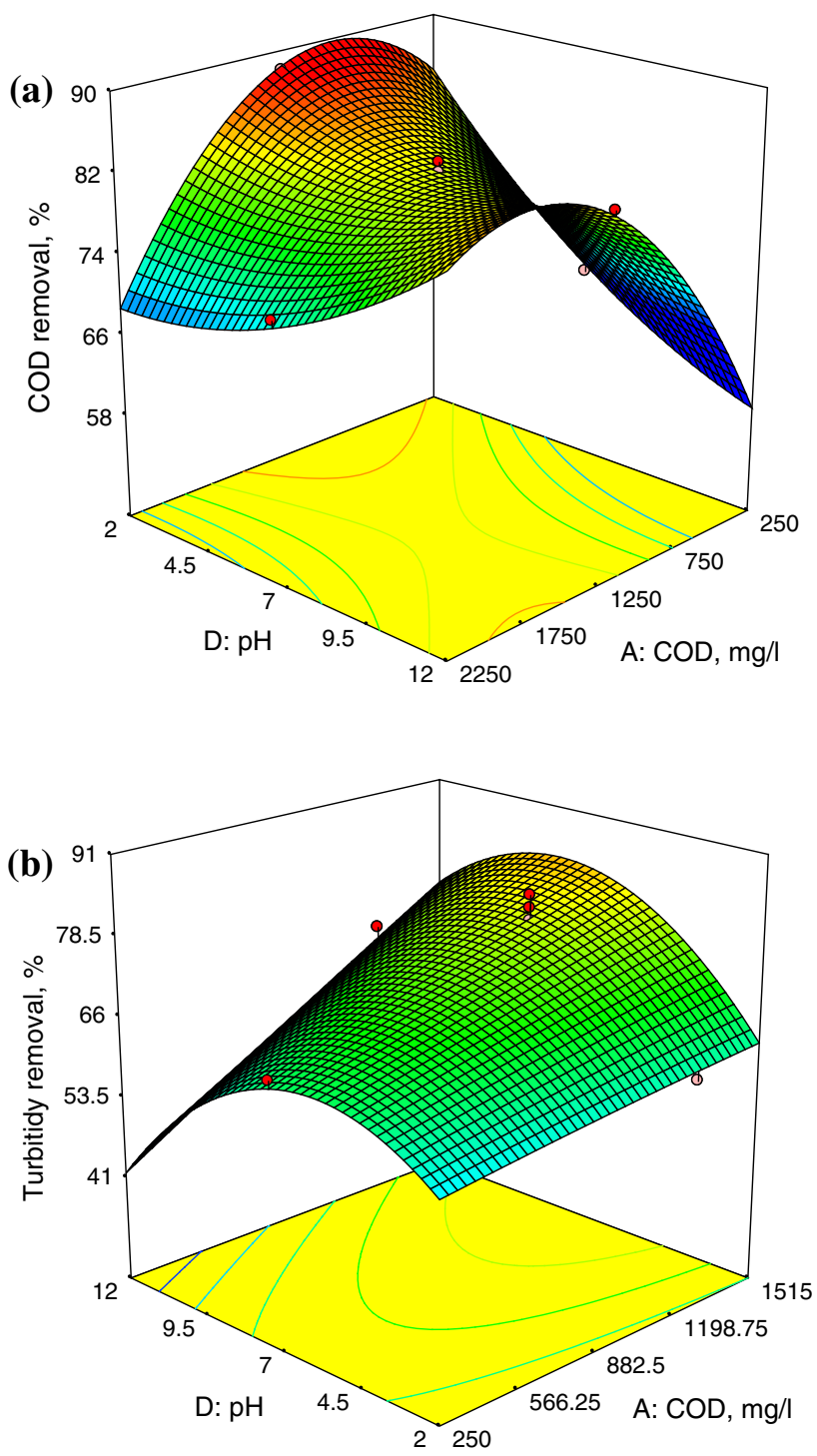

Fig. 4 Effect of initial COD and $\mathrm{pH}$ on a COD removal and b turbidity reduction, while other two variables at its middle level. The colors changes from blue to red in the response value indicating 0 to $100 \%$ range

\section{Sludge volume index (SVI)}

The sludge produced in physical-chemical treatments is due to the organic matter and total solids in suspension that are removed and the compounds formed with the coagulants used, since practically all of the latter become part of the sludge solids. In general, the amount and characteristics of the sludge produced during the coagulation process depend on the coagulants used and on the operating conditions. To observe the volume and settling characteristics, the SVI was determined. The SVI in coagulation process is generally governed by three factors: high polymer effect, osmotic pressure effect and hydration effect (Wang et al. 2007). Figure 5a presents the effect of different levels of 
the alum and PACl dosages on the SVI value when other two variables at its middle level. From this figure, the coagulant dosages of alum coupled with $\mathrm{PACl}$ have a significant interaction on the SVI, as shown in Fig. 5a. The curvilinear profile obtained for SVI is in accordance to the quadratic model. The SVI decreases significantly with coagulant dosage and $\mathrm{pH}$, but is affected mostly by the coagulant dosage. The best condition of the minimum SVI $(140 \mathrm{ml} / \mathrm{g})$ is observed with dosage of $1,140 \mathrm{mg} / \mathrm{l}$ alum and of $1,495 \mathrm{mg} / \mathrm{l} \mathrm{PACl}$. Under strong acid conditions (e.g. $\mathrm{pH}<4.5$ ) and low ranges of COD, the aluminum ions are mostly in the form of $\mathrm{Al}^{3+}$, which is highly effective for decreasing the osmotic pressure and hydration effects. Figure $5 \mathrm{~b}$ presents the effect of different levels of the $\mathrm{pH}$ and the initial COD concentration on the SVI value when the other two variables are at its middle level. All of these factors might be responsible for the much lower SVI under acid conditions (Fig. 5b). These results, observed from the response surface plot, are in good agreement with the fitted model for SVI obtained earlier. Figure 5c presents the effect of different levels of the PACl dose and the initial COD concentration on the SVI value when other two variables at its middle level. From this figure, the results obtained on SVI show that high initial COD values result in high SVI value. With COD of $750 \mathrm{mg} / \mathrm{l}$ (as the COD low limit value introduced to software), SVI value of about $340 \mathrm{ml} / \mathrm{g}$ is achieved, while the maximum value of $375 \mathrm{ml} /$ $\mathrm{g}$ is found at initial COD of $1,750 \mathrm{mg} / \mathrm{l}$.

\section{Optimization using the desirability function}

In the numerical optimization, we choose the desirable goal for each factor and response from the menu. The possible goals are: maximize, minimize, target, within range, none (for responses only) and set to an exact value (factors only). A minimum and a maximum level must be provided for each parameter included. A weight can be assigned to each goal to adjust the shape of its particular desirability function. The goals are combined into an overall desirability function, an objective function that ranges from zero outside of the limits to one at the goal. The selected program in numerical optimization seeks to maximize this function. The goal seeking begins at a random starting point and proceeds up the steepest slope to a maximum. There may be two or more maximums because of curvatures in the response surface and their combination into the desirability function. By starting from several points in the design space, chances improve for finding the best local maximum. A multiple response method was applied for optimizing any combination for four goals, namely, the initial solution $\mathrm{pH}$, alum dosage, $\mathrm{PACl}$ dosage and initial COD. The numerical optimization found a point that maximizes the desirability function. The importance of each goal was
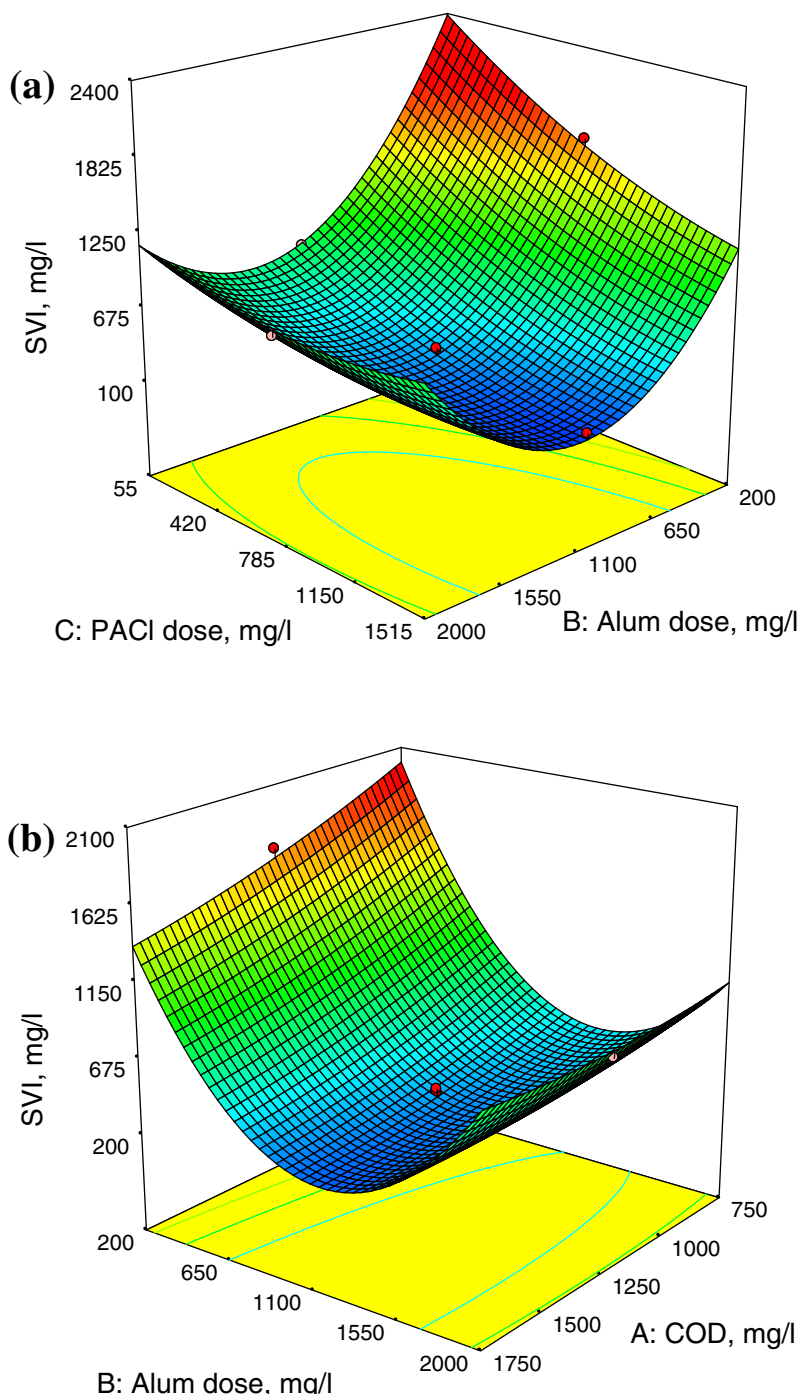

B: Alum dose, mg/l

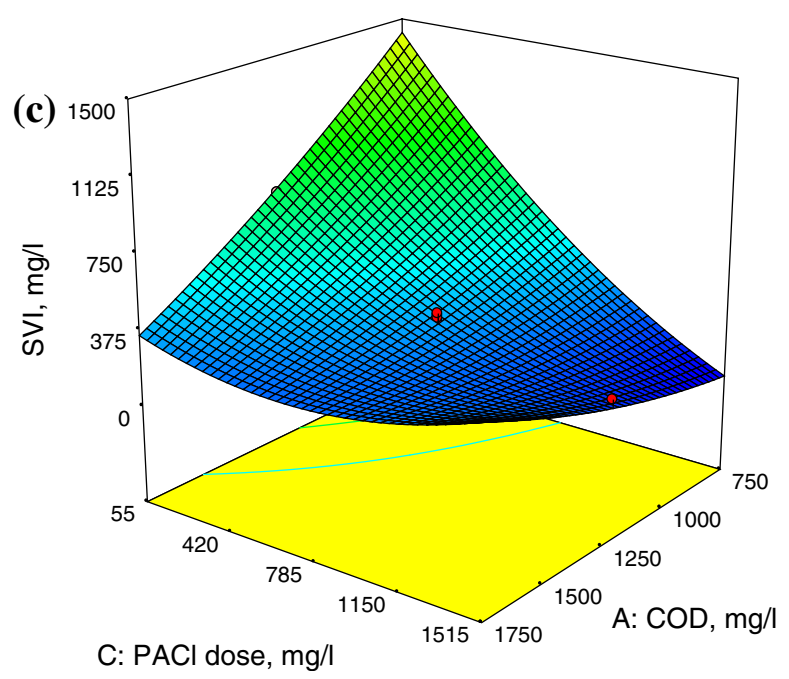

Fig. 5 Surface graphs of SVI showing the effect of variables: a coagulant dosages, $\mathbf{b}$ alum dose and COD and $\mathbf{c} \mathrm{PACl}$ dose and COD. The colors changes from blue to red in the response value indicating 0 to $100 \%$ range 
Table 5 Optimized conditions and results of experiments for final COD and turbidity removal efficiencies and SVI value

\begin{tabular}{|c|c|c|c|c|c|c|c|c|c|c|c|}
\hline \multirow[t]{2}{*}{ No. } & \multicolumn{4}{|c|}{ Variable } & \multicolumn{3}{|c|}{ Predicted value } & \multirow{2}{*}{$\begin{array}{l}\text { Desirability } \\
\text { value }\end{array}$} & \multicolumn{3}{|c|}{ Experimental value } \\
\hline & $\begin{array}{l}\text { COD } \\
(\mathrm{mg} / \mathrm{l})\end{array}$ & $\begin{array}{l}\text { Alum dose } \\
(\mathrm{mg} / \mathrm{l})\end{array}$ & $\begin{array}{l}\text { PACl dose } \\
(\mathrm{mg} / \mathrm{l})\end{array}$ & $\mathrm{pH}$ & $\begin{array}{l}\text { COD } \\
\text { removal }(\%)\end{array}$ & $\begin{array}{l}\text { Turbidity } \\
\text { removal }(\%)\end{array}$ & $\begin{array}{l}\text { SVI } \\
(\mathrm{ml} / \mathrm{g})\end{array}$ & & $\begin{array}{l}\text { COD } \\
\text { removal }(\%)\end{array}$ & $\begin{array}{l}\text { Turbidity } \\
\text { removal }(\%)\end{array}$ & $\begin{array}{l}\text { SVI } \\
(\mathrm{ml} / \mathrm{g})\end{array}$ \\
\hline 1 & 1,750 & 1,550 & 1,314 & 9.5 & 85.32 & 88.36 & 132.24 & 0.936 & 80.02 & 83.23 & 140.00 \\
\hline 2 & 1,736 & 1,320 & 724 & 9.5 & 81.87 & 86.62 & 67.42 & 0.862 & 82.30 & 80.12 & 65.00 \\
\hline 3 & 1,750 & 1,240 & 490 & 9.5 & 81.05 & 88.85 & 104.20 & 0.847 & 85.15 & 82.52 & 112.64 \\
\hline
\end{tabular}

Table 6 Comparison of the present finding with other researchers for the same used coagulants

\begin{tabular}{|c|c|c|c|c|c|c|c|c|}
\hline Wastewater & $\mathrm{pH}$ & $\mathrm{COD}(\mathrm{mg} / \mathrm{l})$ & $\begin{array}{l}\text { Turbidity } \\
\text { (NTU) }\end{array}$ & Coagulant & $\begin{array}{l}\text { Dose of coagulant } \\
(\mathrm{g} / \mathrm{l})\end{array}$ & $\begin{array}{l}\text { COD removal } \\
(\%)\end{array}$ & $\begin{array}{l}\text { Turbidity removal } \\
(\%)\end{array}$ & References \\
\hline \multirow[t]{2}{*}{ Leachate } & \multirow[t]{2}{*}{$8.2-8.5$} & \multirow[t]{2}{*}{$1,794-2,094$} & \multirow[t]{2}{*}{$268-502$} & Alum & 9.5 & 60.8 & 88.9 & \multirow{2}{*}{$\begin{array}{l}\text { Ghafari et al. } \\
\text { (2009) }\end{array}$} \\
\hline & & & & $\mathrm{PACl}$ & 2 & 46.0 & 94.9 & \\
\hline Pulp mill & 9.5 & 1,303 & 10 & $\mathrm{FeCl}_{3}$ & 0.08 & 58.0 & 75.0 & $\begin{array}{l}\text { Rodrigues et al. } \\
\text { (2008) }\end{array}$ \\
\hline Vinasse & 8.4 & 8,525 & 4,600 & $\mathrm{FeCl}_{3}$ & 20 & 99.2 & 84.0 & Zayas et al. (2007) \\
\hline \multirow{2}{*}{$\begin{array}{l}\text { Paper- } \\
\text { recycling }\end{array}$} & \multirow[t]{2}{*}{6.5} & \multirow[t]{2}{*}{3,523} & \multirow[t]{2}{*}{872.5} & Alum & 1.55 & \multirow[t]{2}{*}{82.0} & \multirow[t]{2}{*}{83.2} & \multirow[t]{2}{*}{ Present study } \\
\hline & & & & PACl & 1.31 & & & \\
\hline
\end{tabular}

changed in relation to the other goals. Optimized conditions and results of experiments for final COD and turbidity removal efficiency and SVI value are given in Table 5. The best optimum value for final COD and turbidity removal efficiencies were 80.02 and $83.23 \%$, respectively, and desirability value was close to 1 . The obtained values of desirability showed that the estimated function may represent the experimental model and desirable conditions. In Table 6, the results of this study are compared with the results of other researchers; although wastewater and coagulants differ, but the use of alum coupled with $\mathrm{PACl}$ lead to remove most pollutants from wastewater is corollary to our methods. In our previous published paper, the purpose was aimed to examine the efficiency of alum and $\mathrm{PACl}$ (coagulants) in combination with a cationic polyacrylamide (C-PAMs, i.e., chemfloc $1510 \mathrm{c}$ and chemfloc 3876 as flocculating agents) in the removal of COD and turbidity from paper-recycling wastewater. The results demonstrated that the maximum amounts of $40 \mathrm{mg} / \mathrm{l}$ coagulant dosage and $4.5 \mathrm{mg} / \mathrm{l}$ flocculant dosage at $\mathrm{pH} 4.5$ were required to give $92 \%$ removal of turbidity, $97 \%$ removal of COD and $80 \mathrm{ml} / \mathrm{g}$ value of SVI. However, the best coagulant and flocculant were alum and chemfloc 3876 at a dose of 41 and $7.52 \mathrm{mg} / \mathrm{l}$, respectively, at $\mathrm{pH}$ of 6.85. In these conditions, the highest removal of COD and turbidity and lowest value of SVI were found to be 91.30 and $95.82 \%$ and $12 \mathrm{ml} / \mathrm{g}$, respectively.

\section{Conclusions}

Coagulation process is one of the simple and common physical-chemical methods, advocated to be used for paper-recycling wastewater treatment. Although there are many types of coagulants available to treat water and wastewater, opting the most effective coagulant for a particular wastewater is important. The treatment of pulp and paper mill wastewater using alum coupled with $\mathrm{PACl}$ as coagulants enhanced the reduction removal of turbidity and COD and produced a lower volume of sludge compared to the results obtained when the coagulants were used alone. A desirable functional approach was used to obtain a compromise between three different responses, i.e., COD, turbidity removal and SVI. The optimum conditions obtained were with $1,550 \mathrm{mg} / \mathrm{l}$ alum coupled with $1,314 \mathrm{mg} / \mathrm{l} \mathrm{PACl}$ at $\mathrm{pH} 9.5$, with $80.02 \%$ of $\mathrm{COD}$ removal, SVI of $140 \mathrm{ml} / \mathrm{g}$ and $83.23 \%$ of turbidity removal. The results showed good agreement between the experimental and model predictions.

Acknowledgments The present research was made possible by the sponsorship and financial support of the Ministry of Science of Iran and the Tarbiat Modares University (TMU). The authors wish also to thank Mrs Haghdoust (Technical Assistant of Environmental Laboratory) of TMU for her cooperation and Ellen Vuosalo Tavakoli (University of Mazandaran) for the final editing of the English text. 
Open Access This article is distributed under the terms of the Creative Commons Attribution License which permits any use, distribution, and reproduction in any medium, provided the original author(s) and the source are credited.

\section{References}

Afzal M, Shabir G, Hussain I, Khalid ZM (2008) Paper and board mill effluent treatment with the combined biological-coagulationfiltration pilot scale reactor. Bioresour Technol 99(15):7383-7387

Aghamohammadi N, HbA Aziz, Isa MH, Zinatizadeh AA (2007) Powdered activated carbon augmented activated sludge process for treatment of semi-aerobic landfill leachate using response surface methodology. Bioresour Technol 98(18):3570-3578

Aguilar MI, Sáez J, Lloréns M, Soler A, Ortuño JF (2002) Nutrient removal and sludge production in the coagulation-flocculation process. Water Res 36(11):2910-2919

Ahmad AL, Wong SS, Teng TT, Zuhairi A (2008) Improvement of alum and $\mathrm{PACl}$ coagulation by polyacrylamides (PAMs) for the treatment of pulp and paper mill wastewater. Chem Eng J 137(3):510-517

Anderson-Cook CM, Borror CM, Montgomery DC (2009) Response surface design evaluation and comparison. J Stat Plan Inference 139(2):629-641

APHA (1998) Standard methods for the examination of water and wastewater, 20th edn. American Public Health Association, Washington, DC

Birjandi N, Younesi H, Bahramifar N, Ghafari S, Zinatizadeh AA, Sethupathi S (2013) Optimization of coagulation-flocculation treatment on paper-recycling wastewater: application of response surface methodology. J Environ Sci Health, Part A 48(12): $1573-1582$

Chamarro E, Marco A, Esplugas S (2001) Use of fenton reagent to improve organic chemical biodegradability. Water Res 35(4): 1047-1051

Chaudhari P, Mishra I, Chand S (2007) Treatment of biodigester effluent with energy recovery using various inorganic flocculant. Colloids Surf A Physicochem Eng Aspects 296:238-247

Collins LM, Dziak JJ, Li R (2009) Design of experiments with multiple independent variables: a resource management perspective on complete and reduced factorial designs. Psychol Methods 14(3):202-224

Ghafari S, Aziz HA, Isa MH, Zinatizadeh AA (2009) Application of response surface methodology (RSM) to optimize coagulationflocculation treatment of leachate using poly-aluminum chloride (PAC) and alum. J Hazard Mater 163(2-3):650-656

Helble A, Schlayer W, Liechti P-A, Jenny R, Möbius CH (1999) Advanced effluent treatment in the pulp and paper industry with a combined process of ozonation and fixed bed biofilm reactors. Water Sci Technol 40(11-12):343-350
Hu XJ, Wang JS, Liu YG, Li X, Zeng GM, Bao ZL, Zeng XX, Chen AW, Long F (2011) Adsorption of chromium (VI) by ethylenediamine-modified cross-linked magnetic chitosan resin: Isotherms, kinetics and thermodynamics. J Hazard Mater 185 (1):306-314. doi:10.1016/j.jhazmat.2010.09.034

Kumar R, Singh R, Kumar N, Bishnoi K, Bishnoi NR (2009) Response surface methodology approach for optimization of biosorption process for removal of $\mathrm{Cr}(\mathrm{VI}), \mathrm{Ni}$ (II) and $\mathrm{Zn}$ (II) ions by immobilized bacterial biomass sp. Bacillus brevis. Chem Eng J 146 (3):401-407. doi:10.1016/j.cej.2008.06.020

Kumar P, Teng TT, Chand S, Wasewar KL (2011) Treatment of paper and pulp mill effluent by coagulation. Int $\mathrm{J}$ Civil Environ Eng 3(3):222-227

Latorre A, Malmqvist A, Lacorte S, Welander T, Barceló D (2007) Evaluation of the treatment efficiencies of paper mill whitewaters in terms of organic composition and toxicity. Environ Pollut 147(3):648-655

Nakano E, Jutan A (1994) Application of response surface methodology in controller fine-tuning. ISA Trans 33(4):353-366

Oguz E, Keskinler B (2008) Removal of colour and COD from synthetic textile wastewaters using $\mathrm{O}_{3}, \mathrm{PAC}, \mathrm{H}_{2} \mathrm{O}_{2}$ and $\mathrm{H}_{2} \mathrm{CO}_{3}$. J Hazard Mater 151(2-3):753-760

Petala M, Tsiridis V, Samaras P, Zouboulis A, Sakellaropoulos GP (2006) Wastewater reclamation by advanced treatment of secondary effluents. Desalination 195(1-3):109-118

Rodrigues AC, Boroski M, Shimada NS, Garcia JC, Nozaki J, Hioka N (2008) Treatment of paper pulp and paper mill wastewater by coagulation-flocculation followed by heterogeneous photocatalysis. J Photochem Photobiol A Chem 194(1):1-10

Stephenson RJ, Duff SJB (1996) Coagulation and precipitation of a mechanical pulping effluent-I. Removal of carbon, colour and turbidity. Water Res 30(4):781-792

Thompson G, Swain J, Kay M, Forster CF (2001) The treatment of pulp and paper mill effluent: a review. Bioresour Technol 77(3):275-286

Vohra A, Satyanarayana T (2002) Statistical optimization of the medium components by response surface methodology to enhance phytase production by Pichia anomala. Process Biochem 37(9):999-1004

Wang J-P, Chen Y-Z, Ge X-W, Yu H-Q (2007) Optimization of coagulation-flocculation process for a paper-recycling wastewater treatment using response surface methodology. Colloids Surf Physicochem Eng Aspects 302(1-3):204-210

Zayas T, Rómero V, Salgado L, Meraz M, Morales U (2007) Applicability of coagulation/flocculation and electrochemical processes to the purification of biologically treated vinasse effluent. Sep Purif Technol 57(2):270-276

Ziagova M, Dimitriadis G, Aslanidou D, Papaioannou X, Litopoulou Tzannetaki E, Liakopoulou-Kyriakides M (2007) Comparative study of $\mathrm{Cd}(\mathrm{II})$ and $\mathrm{Cr}(\mathrm{VI})$ biosorption on Staphylococcus xylosus and Pseudomonas sp. in single and binary mixtures. Bioresour Technol 98(15):2859-2865 